PAEDAGOGIA CHRISTIANA

I/21 (2008) - ISSN 1505-6872

Matgorzata Stowik*

Słupsk

\title{
Rozumienie i wartościowanie aktywności społecznej młodzieży - wnioski dla pracy socjalnej
}

\section{Wprowadzenie}

O aktywności społecznej młodzieży pisze się stosunkowo niewiele. To pojęcie - zjawisko kojarzyć można między innymi z budowaniem społeczeństwa, w którym każdy obywatel ma czuć się uczestnikiem, podmiotem, a nie przedmiotem działań politycznych czy społecznych. Co prawda, zauważa się i podkreśla w naszym kraju takie dążenia oraz dostrzega się znaczenie wartości narodowych, wartości scalających społeczeństwo (coraz częściej zwraca się uwagę na rozwój postaw patriotycznych, obywatelskich, czy potrzebę budzenia poczucia wpływu na sprawy publiczne i motywacji do działań na rzecz społeczności lokalnych) ${ }^{1}$, jednak najwięcej publikacji na temat samej aktywności społecznej pochodzi z okresu budowania socjalizmu w Polsce, kiedy to właśnie społeczna aktywność każdego obywatela była wysoce pożądana i, rzec można, poprawna politycznie. $\mathrm{W}$ ustroju socjalistycznym podkreślano potrzebę podporządkowania jednostki grupie, kolektywowi. Trudno było dostrzec w ówczesnej aktywności społecznej dobrowolność czy spontaniczność. Dlatego współczesne rozumienie tego pojęcia różni się zapewne od wcześniejszych ujęć, które aktywność społeczną łączyły głównie z czynami społecznymi (podejmowanymi raczej z obowiązku, niż z własnej woli) oraz z osobami wzorowych działaczy, aktywistów, społeczników² w Słupsku.

* Małgorzata Słowik, adiunkt w Zakładzie Pedagogiki Społecznej Akademii Pomorskiej

${ }^{1}$ Stan spoteczeństwa obywatelskiego w latach 1998-2006, Komunikat z badań CBOS, Warszawa 2006; Czy zwykly obywatel ma poczucie wptywu na sprawy publiczne?, Komunikat z badań CBOS, Warszawa 2007.

${ }^{2}$ Dokładniejszą analizę pojęcia aktywności społecznej w literaturze przedmiotu znajdziemy 
Celem artykułu jest poznanie i analiza zjawiska aktywności społecznej młodzieży $\mathrm{w}$ różnych ujęciach na przestrzeni ostatnich dziesięcioleci (przed, w trakcie i po transformacji ustrojowej). Ważne są tu również wiadomości, które mogłyby inspirować pracowników socjalnych, szczególnie organizatorów społeczności lokalnej, do większego zaangażowania w budzenie aktywności społecznej młodych ludzi.

\section{Różne pojmowanie aktywności społecznej}

Dzieci i młodzież można stopniowo wdrażać do bycia aktywnym społecznie - kształtując ich umiejętności społeczne, ucząc ich społecznych zachowań, stwarzając warunki do stymulowania ich aktywności. Aktywność społeczna staje się wtedy zespołem określonych zachowań jednostki, dzięki którym jednostka świadomie oddziałuje na otoczenie ${ }^{3}$. Staje się też aktywność społeczna elementem procesu uspołeczniania. Elementem i jednocześnie efektem tego procesu. Z takiego pojmowania aktywności społecznej wypływa rola osób odpowiedzialnych za wychowanie młodego człowieka - mają one dbać także o tę sferę rozwoju: bycie, stawanie się dla innych. Dobrze, gdy dzieje się to w sposób niezamierzony, spontanicznie, bo świadczy wtedy o wartościowej motywacji, wypływa nie tylko z poczucia obowiązku, czy spełnienia jakiejś powinności, ale jest wyrazem rzeczywistej, naturalnej dbałości o pełne uczestnictwo w społeczeństwie i dla społeczeństwa.

Zaangażowanie społeczne (które możemy nazwać także aktywnością społeczną) uznaje się za najpełniejszy rodzaj działania ludzkiego. Mobilizuje ono całą osobowość. Do pełnego zaangażowania potrzebny jest świadomy wybór i akceptacja, dzięki któremu budzi się bezinteresowna życzliwość, następuje „przekraczanie siebie”, przełamywanie własnego egocentryzmu. Zaangażowanie społeczne to pochodzące $\mathrm{z}$ wolnego wyboru zupełne oddanie się pewnej sprawie lub konkretnej osobie. Jest to najpełniejszy atrybut uspołecznionej osobowości ${ }^{4}$. Dostrzec można więc kolejne znaczenie pojęcia aktywności społecznej - jest to także cecha osobowości, oznaczająca samą gotowość jednostki do zajmowania się problemami społecznymi, oraz gotowość do działania na rzecz innych ludzi i grup ${ }^{5}$. W tym momencie można zastanowić się, czy aktywność społeczna jest wyrazem zaspokajania potrzeb wyższego rzędu, jakimi są np. potrzeby afiliacji, szacunku i uznania, samorealizacji, czy chodzi tu już o potrzeby nieujęte w zna-

w pracy M. Prokosz. Por. M. Prokosz, Aktywność społeczna młodzieży szkót średnich w środowisku wielkomiejskim, Wrocław 2000.

${ }^{3}$ M. Tyszkowa, Aktywność i działalność dzieci i młodzieży, Warszawa 1990, s. 188.

${ }^{4}$ I. Jundziłł, Uspołecznienie dzieci i młodzieży, w: W. Pomykało (red.), Encyklopedia pedagogiczna, Warszawa 1993, s. 900.

${ }^{5}$ M. Tyszkowa, dz. cyt., s. 188. 
nej piramidzie A. Maslowa, a związane z transcendencją? Zaspokajając potrzeby transcendencji (które można rozumieć jako przekraczanie samego siebie), człowiekowi nie wystarcza już realizowanie własnych planów, marzeń (dotyczących jego życia), ale pragnie on wyjść w swoim działaniu dalej, zwrócić się ku innym, nie po to, by zyskać aprobatę otoczenia, ale przede wszystkim z pobudek duchowych. Wyniki badań CBOS dotyczące religijności społeczników zdają się potwierdzać to przypuszczenie. Znaczna część (ponad połowa) osób wyróżniających się szczególnie wysoką aktywnością społeczną to ludzie silnie związani z Kościołem (obok przedstawicieli kadry kierowniczej i inteligencji) ${ }^{6}$.

Aktywność społeczną uważać też można za przejaw wysokiego stopnia rozwoju i organizacji grupy ${ }^{7}$. Świadczy to o tym, że grupa zaspokaja podstawowe potrzeby swoich członków (na przykład potrzebę bezpieczeństwa, przynależności, akceptacji, samorealizacji) i dzięki temu członkowie grupy zaczynają myśleć o innych, o interesie społecznym, o wspólnym dobru. To grupa jest właściwym miejscem, przestrzenią, w której aktywność społeczna ma szansę się w ogóle pojawić i rozwijać w prawidłowy, wartościowy sposób. Dodatkowo, w grupie, osoby zaangażowane $\mathrm{w}$ działania społeczne czynią to nie indywidualnie, ale we współpracy z innymi. W analizowanym rozumieniu aktywności społecznej szczególnie ważne są więc działania kierowane na osiaganie celów zbiorowych. Przez to uznaje się aktywność społeczną za jeden z mechanizmów sprawowania władzy politycznej - co obecnie (w rozwijającym się społeczeństwie obywatelskim) można rozumieć jako sposób wpływu każdego obywatela (nie tylko grup) na sprawy publiczne.

Zagadnienie aktywności społecznej bywa poruszane w kontekście rozważań na temat działalności niektórych organizacji młodzieżowych. Organizacje te opierają swoją działalność na inicjatywie i aktywności swoich członków. Ich programy obejmują takie elementy uspołecznienia młodzieży, jak: kształtowanie wrażliwości na potrzeby społeczne, czynne angażowanie się na rzecz innych, na rzecz wspólnego dobra. Dzięki temu rozwijane są takie cechy członków organizacji, jak: bezinteresowność, aktywność, solidarność, altruizm ${ }^{8}$. Nie wszyscy

${ }^{6}$ Stan spoleczeństwa..., s. 13, 18; Czy Polacy maja predyspozycje do pracy spolecznej na rzecz swojej społeczności? Komunikat z badań CBOS, Warszawa 2008, s. 13. Pod koniec lat dziewięćdziesiątych była to grupa osób najbardziej aktywnych społecznie (ponad połowa z nich działała w jakiejś organizacji, w tym jedna czwarta - w kilku). W roku 2002 aktywność społeczna tej grupy wyraźnie zmalała (w porównaniu z poprzednimi latami) i na takim poziomie utrzymuje się do dnia dzisiejszego. Por. tamże.

${ }^{7}$ J. Drążkiewicz, Uwagi o aktywności społecznej i zróżnicowaniu społecznym, Studia Socjologiczne 4 (1974), s. 173. W wymienionym artykule autor formułuje i wyjaśnia definicję aktywności społecznej w sposób właściwy socjalistycznej mentalności. Pisze o aktywności społecznej klas i warstw społecznych, o „kolektywizmie celu”, czyli konieczności kierowania aktywności społecznej na osiąganie celów zbiorowych, o powiązaniu aktywności społecznej z mechanizmami sprawowania władzy politycznej. Część jego spostrzeżeń pozostaje jednak wciąż aktualna i warto wykorzystać je do rozważań nad współczesnym kształtem aktywności społecznej.

${ }^{8}$ J. Półturzycki, E. A. Wesołowska, Nie tylko szkoła, Warszawa 1988, s. 93-95. 
jednak członkowie młodzieżowych organizacji muszą być aktywni społecznie. Za aktywnych uważa się tych, którzy nie tylko wykonują powierzone im zadania, ale są przy tym świadomi potrzeby ich wykonania, inicjują i organizują proces zaspokajania potrzeb społecznych. Ważne jest więc rozumienie sensu własnej aktywności społecznej.

Aktywność społeczna bywa elementem aktywności społeczno-politycznej i w tym kontekście rozumiana jest jako działalność zbiorowa, zorganizowana lub spontaniczna, która ma służyć realizacji celów samej organizacji, grup, społeczności lub całego społeczeństwa ${ }^{9}$ (takie cele można określić jako zbiorowe). Jest wtedy bardziej widoczna niż działalność pojedynczych osób czy grup nieformalnych. W opinii potocznej aktywność społeczną łączy się ściśle z działalnością polityczną, mimo że nie jest to zgodne z empiryczną wiedzą na ten temat. Aktywność społeczna może przejawiać się w działalności politycznej, czy jej towarzyszyć. Wiemy jednak, że tych przejawów aktywności społecznej jest więcej (należą do nich na przykład akcje społeczne, wolontariat, inicjatywy społeczne). Warto wziąć to pod uwagę i uświadamiać to na przykład rodzicom, których zamierza się przekonywać o potrzebie budzenia aktywności społecznej ich dorastających dzieci. W rozmowie z nimi trzeba uwzględnić ich świadomość, opinie i postawy, jakie ukształtowały się w stosunku do tego zagadnienia na przestrzeni ostatnich dziesięcioleci. Jeśli odnoszą oni pojęcie aktywności społecznej jedynie do sfery działalności politycznej (z którą mają na dodatek negatywne skojarzenia), warto ukazać im jego szerszą perspektywę.

Temat aktywności społecznej pojawia się w dyskusjach nad potrzebą budowania społeczeństwa obywatelskiego we współczesnej demokratycznej Polsce i wówczas aktywność społeczna rozumiana jest bardziej jako obywatelskie zainteresowanie i zaangażowanie w sprawy publiczne, sprawy państwa (aktywność obywatelska). Staje się fundamentem społeczeństwa obywatelskiego. Może przejawiać się w udziale obywateli w wyborach, w otwartym wyrażaniu swoich poglądów (uczestnictwie w debatach publicznych poruszających kwestie istotne dla kraju, regionu i społeczności lokalnej), w zwracaniu uwagi władz na istotne problemy, w protestowaniu przeciw ich błędnym i niesprawiedliwym decyzjom, a także w innych formach działania na rzecz drugiego człowieka - w szczególności zaś w „pomocy dla samopomocy” (chodzi tu szczególnie o wspieranie i działanie w organizacjach pozarządowych). Bez aktywności społecznej obywateli społeczeństwo obywatelskie nie ma szans zaistnieć i prawidłowo rozwijać się. Bazuje przecież na władzy samorządowej, a w skład samorządów wchodzić mają ludzie gotowi pomagać innym, przejawiający zaufanie do nich (również do instytucji publicznych) ${ }^{10}$.

${ }^{9}$ M. Eckert, H. Samujłło, Świadomość i aktywność społeczno-polityczna młodzieży, w: J. Bogusz (red.), Młodzież polska u progu lat dziewięćdziesiatych, Warszawa 1991, s. 51.

${ }^{10}$ Termin społeczeństwo obywatelskie został wprowadzony przez G. W. F. Hegla. Rozpowszechniany był przez innych filozofów, między innymi przez K. Marksa. Do myśli społeczeń- 


\section{Aktywność spoleczna i wolontariat}

Z aktywnością społeczną kojarzyć można pracę wolontarystyczną. Wolontariat to jeden z przejawów tej aktywności. Definicja sformułowana przez stowarzyszenie Centrum Wolontariatu określa wolontariat jako „bezpłatne, dobrowolne, świadome działanie na rzecz innych, wykraczające poza więzi rodzinno-koleżeńsko-przyjacielskie" ${ }^{11}$. Ustawa o działalności pożytku publicznego i o wolontariacie z 2003 roku definiuje natomiast wolontariusza jako osobę fizyczną, która wykonuje świadczenia dobrowolnie i bez gratyfikacji materialnej na rzecz organizacji pozarządowych, organów administracji publicznej i podległych im jednostek organizacyjnych ${ }^{12}$. Praca wolontarystyczna zakłada działania rozłożone w czasie, rzadko bywa świadczeniem jednorazowym. Jeśli takim jest, uznać ją można raczej za inny przejaw aktywności społecznej niż wolontariat, na przykład za udział w społecznej akcji, czy podjęcie społecznej inicjatywy. Współczesny wolontariat wymaga poza tym odpowiedniego przygotowania, zobowiązań zarówno ze strony wolontariuszy, jak i osób koordynujących ich pracę (służy temu odpowiednio sporządzona umowa, o której informuje wspomniana wyżej ustawa).

Wyłania się tu konieczność określenia różnic między pojęciem pracy wolontarystycznej, a pojęciem aktywności społecznej. Mimo że znaczenie tych pojęć w pewnej mierze nakłada się na siebie, to jednak istnieją istotne różnice między nimi. Wolontariat to pojęcie węższe od pojęcia aktywności społecznej, wchodzi w jej skład, może być jej przejawem, świadczyć o niej. Aktywność społeczna jest nie tylko pracą wolontarystyczną, ale przejawiać może się również w innych formach, na przykład w organizowaniu, czy udziale w akcjach społecznych, w pełnieniu określonych funkcji w samorządach szkolnych, studenckich, czy lokalnych.

\section{Przełom w wartościowaniu aktywności społecznej}

W okresie transformacji ustrojowej odsunięto się nieco od problematyki aktywności społecznej (mimo że upatruje się w niej podstawę rozwoju społeczeń-

\footnotetext{
stwa obywatelskiego nawiązywały ruchy liberalne, socjaldemokratyczne i socjalistyczne. Według nich, społeczeństwo obywatelskie oparte ma być na sieci niezależnych od władzy publicznej i samodzielnie tworzonych przez obywateli organizacji o różnym charakterze. Istotnym składnikiem takiego społeczeństwa jest samorząd. Mianem społeczeństwa obywatelskiego określa się takie społeczeństwo, w którym do minimum ograniczona jest ingerencja władzy politycznej w życie obywateli. W takim społeczeństwie obywatele $\mathrm{z}$ własnej inicjatywy tworzą odpowiadające ich potrzebom formy życia gospodarczego, społecznego i kulturalnego. Por. P. Winczorek, Wstęp do nauki o państwie, Warszawa 2000, s. 117.

${ }^{11}$ J. Herbst, M. Gumkowska (Stowarzyszenie Klon/Jawor), Wolontariat, filantropia i 1\%. Raport z badań 2006, Warszawa 2007, s. 6.

${ }^{12}$ Por. Ustawa z dnia 24 kwietnia 2003 roku o działalności pożytku publicznego i o wolontariacie.
} 
stwa obywatelskiego, którego wartość uznają przecież zwolennicy demokracji) - potrzeba społecznego aktywizowania młodzieży wydawała się mniej nagląca w porównaniu na przykład z przygotowaniem młodych ludzi do udanego wejścia na nowy rynek pracy. Nauczyciele i wychowawcy - dotychczasowi „,unkcjonariusze" odpowiedzialni za społeczną aktywizację młodych - zostali zwolnieni z tego obowiązku. Skupiono się na przygotowaniu i wdrażaniu zmian związanych z reformą oświaty. Pojawiło się poza tym tyle atrakcyjnych możliwości dla młodego pokolenia (otwarte granice, dostęp do informacji, swoboda wypowiedzi), a z drugiej strony tyle problemów, zagrożeń (bezrobocie, wzrastająca przestępczość), że poświęcanie swego wolnego czasu na działalność społeczną schodziło na dalszy plan ${ }^{13}$. Pokolenie rodziców zaczęło uświadamiać swoje dorastające dzieci, że teraz, w warunkach wolnej demokratycznej Polski, warto działać przede wszystkim na rzecz samego siebie, że liczy się sukces osobisty, że trzeba brać życie w swoje ręce, nie liczyć na innych - na kolegów, nauczycieli, na państwo. Ci rodzice, borykając się z wymogami nowej rzeczywistości - niepokojąc się o własną pracę, przyszłość, chcąc zaoszczędzić swoim dzieciom podobnych doświadczeń - kładli nacisk głównie na taką aktywność pozaszkolną która zwiększy szanse ich dzieci na dobry start w dorosłość. Uczestnictwo w organizacjach młodzieżowych przegrywało więc często z kursami języków obcych, rozwojem różnych indywidualnych talentów i zdolności, planowaniem kariery zawodowej.

W ostatnich latach zmieniło się jednak podejście dorosłych do zagadnień związanych z aktywnością społeczną. Systematycznie rośnie liczba osób wierzących w skuteczność wspólnego działania z innymi na rzecz swojego środowiska lub osób potrzebujących - obecnie stanowią oni większość społeczeństwa. Utrzymuje się ponadto znaczna gotowość badanych osób do podejmowania współpracy na rzecz swojej społeczności lokalnej lub osób potrzebujących ${ }^{14}$. Można więc żywić nadzieję, że takie postawy pokolenia dorosłych znajdą swoje odzwierciedlenie także w nastawieniu współczesnej młodzieży do działań społecznych.

Wracając do czasów transformacji ustrojowej, zaznaczyć należy jeszcze, że młodzież tamtego okresu dostrzegała problemy i potrzeby społeczne, ale rzadko angażowała się w ich rozwiązywanie. Wiedziała, że pomoc innym jest cenioną wartością, ale decydowała się pomagać najpierw samej sobie. Istniały jednak wówczas, i istnieją do dziś, organizacje młodzieżowe, na przykład harcerstwo, które nie zawiesiły swojej działalności na ten trudny czas, ale wręcz odświeżyły swoje podejście i odpowiedziały na potrzeby społeczne, stworzyły korzystną alternatywę dla różnych innych form spędzania czasu wolnego przez młodzież ${ }^{15}$.

${ }^{13}$ Por. H. Świda-Zięba, Obraz świata i bycia w świecie, Warszawa 2000, s. 260-268.

${ }^{14}$ Stan społeczeństwa..., s. 17. Rzeczywiste zaangażowanie obywateli w rozwiązywanie problemów swojego środowiska i pomoc osobom potrzebującym wypada jednak skromniej.

${ }^{15}$ Obecnie działalność tych organizacji cieszy się poparciem władz lokalnych, co wynika z wdrażania odpowiedniej polityki rozwoju społeczności lokalnych w poszczególnych ośrodkach wiejskich i miejskich. 
Poza tym, dostrzec możemy po roku 1989 powodzenie kilku głośnych akcji społecznych, których inicjatorami i uczestnikami byli głównie ludzie młodzi (na przykład: Wojna z trzema schodami, Wielka Orkiestra Świątecznej Pomocy, Łańcuch Czystych Serc). Można przypuszczać, że oni zawsze interesowali się tym, co dzieje się wokół i, co ważniejsze, mieli poczucie sprawstwa, wpływu na otaczającą ich rzeczywistość. Fakt ten można też tłumaczyć ponadczasową, niezależną od warunków historycznych wrażliwością i gotowością niektórych ludzi do niesienia pomocy drugiemu człowiekowi. W szczególny sposób czują się oni odpowiedzialni i solidarni z resztą społeczeństwa.

Dużą rolę w kształtowaniu takich postaw odgrywa rodzina. Jeśli w rodzinnym domu porusza się kwestie społeczne, wyraża się gotowość niesienia pomocy innym ludziom, również tym spoza własnego środowiska, dorastającym dzieciom łatwiej uwierzyć, że także one mają wpływ na to, co się wokół nich dzieje, że są za to wręcz odpowiedzialne. Biografie znanych społeczników (na przykład Marka Kotańskiego ${ }^{16}$, Janiny Ochojskiej ${ }^{17}$ ) pokazują że ich rodziny miały istotny wpływ na kształtowanie światopoglądu i zachowań ukierunkowanych na pomoc drugiemu człowiekowi.

Nietrudno zauważyć, że współcześni społecznicy bywają mniej „widzialni” niż ich poprzednicy z epoki Polski socjalistycznej, powojennej, międzywojennej czy pozytywistycznej. Można rozważyć kilka możliwych przyczyn takiego stanu. Może rzeczywiście jest teraz mniej społeczników niż w poprzednich epokach? Jeśli odpowiemy na to pytanie pozytywnie, to rodzi się następne: skąd tak intensywny rozwój tzw. trzeciego sektora oraz rozwój ruchu wolontarystycznego? Może więc zbyt mało się mówi o współczesnych społecznikach? Postacie społeczników rzadko kiedy stają się bohaterami pierwszych stron gazet, audycji radiowych, reportaży (w przeciwieństwie do zwyczajów minionej epoki socjalizmu).

W budzeniu aktywności społecznej młodych ludzi istotną rolę, oprócz rodziny, ma odgrywać szkoła. W szkolnych programach wychowawczych i profilaktycznych zawsze kładziono akcent na kształtowanie umiejętności społecznych, wartość pracy zespołowej, na potrzebę uwrażliwienia młodzieży na dobro innych ludzi itp., angażowanie jej w pomoc słabszym. Ostatnie lata pokazują jednak dyrektorom szkół, pedagogom, rodzicom, że wymienione wyżej efekty w dużej mierze pozostają nieosiagalne, pozostają w sferze życzeń, czego dowodem są częste, niepokojące incydenty, o których informują media. Większość z nich dotyczy problemu przemocy w szkole (którego doświadczają zarówno uczniowie, jak i nauczyciele).

Nasuwa się refleksja, że zbyt rzadko lub w nie dość atrakcyjny sposób zachęca się młodych, by zechcieli pomagać nie tylko samym sobie, ale by wychodzili z pomocą do innych, interesowali się tym, co dzieje się nie tylko w szkole, ale

${ }^{16}$ Por. Życie bogate i twórcze. Biografia Marka Kotańskiego, http://monar.info.pl (01.12.07).

${ }^{17}$ W. Bonowicz, Niebo to inni, Kraków 2000. 
i w ich najbliższym otoczeniu. Ciagge ujawnianie się i nasilenie patologii społecznych (związanych z negatywnymi skutkami transformacji ustrojowej), takich jak na przykład rozpowszechniająca się wciąż narkomania czy alkoholizm, nakazuje w końcu dostrzegać i poważnie traktować wartość społecznego aktywizowania młodzieży. Nikt nie ma bowiem tak skutecznego wpływu, a przede wszystkim tak ułatwionego dostępu do młodych ludzi, jak ich rówieśnicy. Dlatego pomoc dorosłych w inspirowaniu młodzieży do działań samopomocowych jest w tym przypadku szczególnie wskazana.

\section{Organizator społeczności lokalnej a aktywizacja społeczna młodzieży}

Szansę na świeże spojrzenie, wiarę w możliwość społecznego angażowania młodzieży dają niektóre dyrektywy pomocy społecznej, w myśl których rozwijać się powinna trzecia klasyczna metoda pracy socjalnej - organizowanie środowiska lokalnego ${ }^{18}$. Poza tym, działalność wielu organizacji pozarządowych, niezależna od publicznej pomocy społecznej (w tym także działalność wielu organizacji kościelnych), nastawiona jest właśnie na pracę w środowisku lokalnym, w oparciu o jego potrzeby, możliwości, potencjał.

Potrzeba organizowania społeczności lokalnej ${ }^{19}$ narodziła się jako dopełnienie wcześniej stosowanych metod pracy socjalnej (pracy z indywidualnym przypadkiem i pracy z grupa), które często okazują się niewystarczające i nie w pełni skuteczne. Prowadzą też niekiedy paradoksalnie do zjawiska tzw. marginalizacji jednostek i całych grup, a w konsekwencji do tzw. wykluczenia społecznego. Jeśli zgodnie z założeniami metody organizowania społeczności lokalnej, w proces profilaktyki lub pomocy zaangażujemy różne osoby, grupy z jednego środowiska, maleje ryzyko marginalizacji osób potrzebujących, a wzrasta na przykład szansa na rozwój kapitału społecznego danej społeczności. Kapitałem społecznym można określić stosunki międzyludzkie, oparte na określonych wartościach i normach (takich jak szacunek, tolerancja, solidarność), służących dobru wspólne$\mathrm{mu}^{20}$. Dzięki wysokiemu kapitałowi społecznemu rośnie między innymi poziom wzajemnego zaufania ludzi do siebie, poczucie bezpieczeństwa czy gotowość niesienia pomocy drugiemu człowiekowi.

Samo organizowanie społeczności lokalnej jest procesem, w którym właśnie społeczność określa swoje potrzeby lub cele, ustala ich hierarchię, znajduje

${ }^{18}$ Ustawa z dnia 12 marca 2004 roku o pomocy społecznej, dział II, rozdz. I, art. 45, pkt. 1.

${ }^{19}$ Społeczność lokalna - sieć osobistych powiązań, kontaktów grupowych, tradycji i wzorców zachowania, które powstają na konkretnym obszarze i w określonej sytuacji społeczno-gospodarczej. Por. A. Banaszak-Dankowska, B. Bąbska, A. Dunajska, Praca socjalna w środowisku lokalnym, Warszawa 2005, s. 9.

${ }^{20}$ Społeczność lokalna może rozwijać się dzięki trzem rodzajom kapitałów: k. fizycznemu (dobra materialne posiadane przez poszczególnych członków społeczności), k. ludzkiemu (wiedza i umiejętności ludzi tworzących daną społeczność) i k. społecznemu. 
zasoby potrzebne na ich zaspokojenie czy realizację, a przez odpowiednie działania w tym względzie rozwija i udoskonala postawy i praktykę współpracy oraz wspólnego działania ${ }^{21}$. Organizowanie społeczności lokalnej to proces, którego podstawą jest interesująca nas w tym artykule aktywność społeczna.

Do rozwijania takiego procesu warto, i z pewnością można, pobudzić i zaangażować młodzież. Jeśli więc pracownik socjalny, lub lepiej zespół pracowników, dostrzeże niektóre z korzyści aktywizowania młodzieży, łatwiej mu będzie ten proces zainicjować. Analizując różne sposoby pojmowania pojęcia aktywności społecznej, należy zwrócić uwagę szczególnie na: pojmowanie aktywności społecznej jako cechy osobowości i element procesu uspołecznienia oraz uznawanie aktywności społecznej za fundament społeczeństwa obywatelskiego. Skoro zaangażowanie społeczne jest najpełniejszym rodzajem ludzkiego działania, pozwala ,przekraczać samego siebie”, przełamywać własny egocentryzm, to nie ma lepszego sposobu na profilaktykę i walkę z problemami społecznymi (przemocą rówieśniczą, uzależnieniami, zachowaniami autodestrukcyjnymi). Ważne, by nie tylko pracownicy socjalni, ale wszystkie osoby odpowiedzialne za wychowanie młodego pokolenia to zauważyły. Aby dostrzegli i uznali aktywność społeczną za cechę dojrzałej osobowości, za przejaw osiągania pełni człowieczeństwa. Żadna inna cecha osobowości nie wyróżnia nas tak wyraźnie od świata zwierząt, jak właśnie gotowość poświęcenia siebie dla drugiej osoby.

Na aktywność społeczną można spojrzeć też z innej perspektywy. Uznaje się ją za fundament społeczeństwa obywatelskiego, które charakteryzuje się świadomością poszczególnych osób co do potrzeb ich wspólnoty oraz dążeniem do wspólnego zaspokajania tych potrzeb - to dążenie jest właśnie aktywnością społeczną. Jakie znaczenie ma takie rozumienie aktywności społecznej dla pracownika socjalnego? Dobrze zorganizowana i prężnie działająca społeczność lokalna (element społeczeństwa obywatelskiego) to przede wszystkim godny i przydatny jego „współpracownik”. W takiej społeczności pracownik nie jest sam, ma wielu sprzymierzeńców, na których realnie może liczyć (zaczynając od specjalistów różnych profesji, pracowników różnych instytucji i organizacji, a kończąc na zwykłych mieszkańcach). Korzyści organizowania społeczności lokalnej, aktywizowania młodzieży ją zamieszkującej, wydają się tak oczywiste. A jednak przeszkody stojące na drodze rozwoju tego procesu wciąż okazują się je przewyższać. Pracownicy socjalni, sceptycznie nastawieni do działań aktywizujących społeczność (w tym również społeczność młodzieży), swoje stanowisko argumentują: nadmiernym obciążeniem pracą, koniecznością zajmowania się najbardziej „palącymi” sprawami, koniecznością wykonywania rozbudowanych procedur biurowych i administracyjnych oraz niedostateczną znajomością konkretnych technik umożliwiających wprowadzanie metody organizowania

${ }^{21}$ M. Cohen, Community Organization and Illustration of Practice, w: A. Fink, The Field of Social Work, New York 1978 (za: A. Banaszak-Dankowska, B. Bąbska, A. Dunajska, dz. cyt., s. 25). 
społeczności lokalnej $\mathrm{w}$ życie ${ }^{22}$. Nie bez znaczenia jest też pewna cecha interesującej nas metody - na efekty jej stosowania trzeba długo czekać (a przy tym liczyć się z wystapieniem różnych porażek). Nie znaczy to jednak, że organizowanie społeczności lokalnej nie ma w ogóle miejsca w praktyce polskiej pracy socjalnej. Istnieją ośrodki, które mogą pozwolić sobie na zatrudnianie pracowników socjalnych specjalizujących się w opisywanej metodzie (na przykład Gdańsk, Poznań). Poza tym organizacje pozarządowe mają w tym zakresie więcej możliwości i wydają się bardziej otwarte i przygotowane do stosowania tej metody. Dlatego wciąż warto podejmować dyskusje i uświadamiać im znaczenie aktywizowania młodzieży.

Zaznaczono wcześniej (opisując przełom w wartościowaniu aktywności społecznej) niektóre przejawy umacniania się społeczeństwa obywatelskiego w Polsce. Nie powinny one uchodzić uwadze pracowników socjalnych. Znaczna część społeczeństwa dorosłych (deklarujących gotowość niesienia pomocy innym, posiadających już jakieś doświadczenia w takich działaniach) oraz młodzież już społecznie zaangażowana, będąca członkami różnych organizacji młodzieżowych, mogą stać się sprzymierzeńcami pracowników socjalnych. Podobnie szkoły, w których dostrzega się wartość i wspiera społeczne zaangażowanie młodzieży, mogłyby pomóc i jednocześnie skorzystać ze współpracy z pomocą społeczną. W celu aktywizowania społecznego młodzieży pracownicy socjalni, a dokładniej zatrudniające ich instytucje, mogą zaoferować swoim potencjalnym sprzymierzeńcom możliwości szkolenia liderów, animatorów, zagwarantować dostęp do potrzebnych informacji, na przykład informować zainteresowanych o sytuacji socjalnej na danym terenie, o aktualnych problemach, potrzebach społecznych. Możliwości współpracy pracowników socjalnych ze społecznością lokalną w zakresie społecznego aktywizowania młodzieży są naprawdę bogate.

\section{Podsumowanie}

Współczesne rozumienie aktywności społecznej czerpie podstawy z refleksji minionego okresu (przed transformacja ustrojową), odrzucając niektóre elementy i podkreślając dotąd niedoceniane. Chodzi tu szczególnie o rodzaj motywacji. Podejmowanie aktywności społecznej nie może wynikać z zewnętrznych nakazów, nie powinno być wynikiem przymusu, narzucenia obowiązku, ale raczej konsekwencją odpowiedzialnego uspołeczniania jednostki, jej świadomego autonomicznego wyboru. Wówczas aktywność ta jest najbardziej wartościowa, zarówno dla osoby aktywnej, jak i dla społeczeństwa. Obecnie podkreśla się też korzyści płynące z podejmowania aktywności społecznej, zarówno dla osób aktywnych, jak i dla ich otoczenia oraz szerzej, dla środowiska społecznego -

${ }^{22}$ P. Oniszczuk, Zaproszenie do organizowania społeczności lokalnej, Pomost 9 (1999); http://www.zwo.nhl.nl/matra/matra_pl/Welcome_POMOSTU_9909_PL.htm (29.02.2008). 
w aktywności społecznej upatruje się warunek i przejaw rozwoju społeczeństwa obywatelskiego.

Pracownicy socjalni - organizatorzy społeczności lokalnej - współpracowników w działaniach na rzecz drugiego człowieka znajdą między innymi wśród młodzieży, o ile zechcą ją do tego odpowiednio przygotować (poprzez informowanie o problemach, potrzebach społecznych, budzenie refleksji nad nimi, szkolenie w zakresie umiejętności reagowania na nie, niesienia pomocy itp.). Chcąc budzić aktywność społeczną młodzieży, pracownicy socjalni mają do wykorzystania (poza własną wiedzą i doświadczeniem) kontakty ze szkołami i z tymi dorosłymi członkami społeczności lokalnej, którzy już są społecznie zaangażowani (lub choćby wyrażają gotowość takiego zaangażowania).

\section{The understanding and the estimating the social activity of youth - conclusions for social work} (Summary)

There was relatively little written about the social activity of youth. It is the conception - phenomenon, which may be associated, inter alia, with the society development, where every citizen has to feel as the participant and subject, not the object of political and social actings. Although such trend is being noticed and emphasized in our country, as well as the importance of national values, integrating the society (it is more and more often to pay attention to development of patriotic and civil attitudes, as well as the necessity of stimulating the sense of real influence on public affairs and the motivation for the workings on behalf of local communities), however the majority of Polish publications concerning strictly the social activity was actually issued before the ' 90 s, in the socialism's regime, when the social activity of every citizen's was highly desirable and, may be said, politically correct.

The main object of present article is to identify and analyse the phenomenon of social activity of youth, in formulation of different scientific disciplines, as well as the organizations and social groups, in the period of last few decades (before, under and after the transformation of politic system in Poland). The accent is also being put to inspire the social workers, especially the local community workers, to increase their engagement in stimulating the social activity of the youth. 